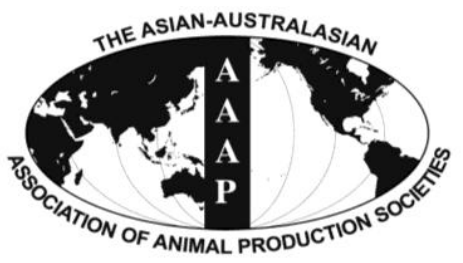

Asian Australas. J. Anim. Sci.

Vol. 26, No. 8 : 1197-1204 August 2013

http://dx.doi.org/10.5713/ajas.2013.13060

www.ajas.info

pISSN 1011-2367 elSSN 1976-5517

\title{
Properties of Milk Supplemented with Peanut Sprout Extract Microcapsules during Storage
}

\author{
Y. K. Lee, P. Ganesan, and H. S. Kwak* \\ Department of Food Science and Technology, Sejong University, Seoul 143-747, Korea
}

\begin{abstract}
This study was carried out to investigate the physicochemical and sensory properties of milk with added powdered peanut sprout extract microcapsules (PPSEM) during the storage at $4{ }^{\circ} \mathrm{C}$ for $16 \mathrm{~d}$. The size of PPSEM varies from 3 to $10 \mu \mathrm{m}$ as observed by the scanning electron microscopy (SEM). The $\mathrm{pH}$ values of all samples ranged from 6.8 to 6.6 during the storage. Release of resveratrol for 0.5 and $1 \%$ PPSEM addition was about $0.89 \mu \mathrm{l} / \mathrm{ml}$ and TBARS value found to lower during storage of $16 \mathrm{~d}$. The $\mathrm{a}^{*}$ and $b^{*}$ color values of high concentrations $(1.5,2.0,2.5$ and 3.0\%) of PPSEM-added milk samples were significantly increased during the storage $(\mathrm{p}<0.05)$. The sensory test revealed that the overall acceptability of PPSEM $(0.5$ and $1 \%)$ added milk sample were quite similar to that of control. Based on the data, it was concluded that the low concentrations of the microcapsules $(0.5$ and $1.0 \%$, w/v) could be suitable to produce the microcapsule-supplemented milk without significant adverse effects on the physicochemical and sensory properties of milk. (Key Words: Milk, Microencapsulation, Peanut Sprout Extract, Physicochemical Properties, Sensory Properties)
\end{abstract}

\section{INTRODUCTION}

Resveratrol (3, 4', 5-trihydroxystilbene) is a natural polyphenolic compound which is found both as trans and cis isomers with trans form being the more biologically active (Burns et al., 2002). The beneficial effects of resveratrol are proven by numerous animal and human studies. It has been reported that it has anticancer, antiinflammatory, blood sugar-lowering and anti-arthritic effects (King et al., 2006). Resveratrol reveals the antiinflammatory properties as it suppresses cyclooxygenase-2 (COX-2) by blocking improper up-regulation of NF-kB, such as occurs in some cancer cells (Subbaramaiah et al., 1998; Surh et al., 2001). The estrogenic activity of resveratrol may also help prevent bone loss in postmenopausal women (Mizutani et al., 1998). Resveratrol is mostly found in red wine, red grape skin, peanut and peanut butter. The grapes, grape vine and red wines contain resveratrol ranged from 0.03 to $7.17 \mu \mathrm{g} / \mathrm{g}$ (Gurbuz et al., 2007). Other known sources of resveratrol are cranberry juice $(0.24 \mu \mathrm{g} / \mathrm{g})$, strawberry $(0.11 \mu \mathrm{g} / \mathrm{g})$, blueberry $(0.02$ to $0.03 \mu \mathrm{g} / \mathrm{g}$ ) and peanuts (0.01 to $1.79 \mu \mathrm{g} / \mathrm{g}$ ) (Wang et al., 2002; Lyons et al., 2003; Tokusoglu et al., 2005). However,

\footnotetext{
* Corresponding Author: H. S. Kwak. Tel: +82-2-3408-3226, Fax: +82-2-3408-4319, E-mail: kwakhs@sejong.ac.kr Submitted Jan. 23, 2013; Accepted Mar. 5, 2013; Revised Apr. 5, 2013
}

the most abundant source of resveratrol is peanut sprout extract with an average content of $110.05 \mu \mathrm{g} / \mathrm{g}$ (Kang et al., 2010).

Even though peanut sprouts have proven health benefits, resveratrol in peanut sprout extract is extremely vulnerable to oxidants, light and heat. In order to overcome those problems and to enable peanut sprouts to be utilized in functional foods, microencapsulation can be a possible solution. Microencapsulation, a technique for encapsulating particles or droplets by coating materials, has been widely applied in the food industry to mask off-taste or hide the core color, prevent oxidation and protect functional ingredients (Gharsllaoui et al., 2007).

Recently, as a microencapsulation technique, W/O/W emulsion has been used for improving stability, storage and bioavailability. W/O/W emulsion is a multicompartmental system obtained from the preparation of a primary emulsion which is then re-emulsified using secondary emulsifiers. To ensure better stability, W/O/W emulsion has become a common practice in the food industry, such as bayberry microencapsulation coated with ethyl cellulose (Zeng et al., 2011), shrimp feedstuff coated with maltodextrin (PedrozaIslas et al., 1999) and other sensitive food ingredients. Spray drying microencapsulation is useful for several food ingredients, such as flavor compounds (Cho et al., 2000) and polysaccharides (Adachi et al., 2004). Thus, the 
impediments to peanut sprout extract application can be mostly overcome by spray dry technology for high stability and protection against oxidation.

Apart from the high nutritive value of milk, some consumers demand special functional properties in milk. Therefore, over the years, a variety of food ingredients, such as L-ascorbic acid (Lee et al., 2004), isoflavone (Jeon et al., 2005), fish oil (Fonolla et al., 2009) and Inonotus obliquus extract powder (Ahn et al., 2010) have been used in milk as microcapsules to improve the functional properties.

Nowadays consumers are more health conscious than ever. To meet the growing demand for food with health promoting functions, functional milk can be developed using the appropriate nutraceutical ingredients, such as peanut sprout extract. However, there is limited information on developing functional milk which incorporates powdered peanut sprout extract microcapsules. Therefore, the objective of the present study was to evaluate the physicochemical and sensory properties of the microcapsule-supplemented milk during storage.

\section{MATERIALS AND METHODS}

\section{Materials}

Peanut sprout extract $(1 \mathrm{mg} / \mathrm{ml})$ as a core material was offered by Jangsuche. Co., Ltd. (Seoul, Korea). MCT (medium-chain triglyceride) as a primary coating material was provided by Wellga Co., Ltd. (Seongnam, Korea). Whey protein concentrate (WPC 80\%) (Davisco Foods International, MN, USA) was used as a secondary coating material. As emulsifiers, polyglycerol polyricinoleates (PGPR, HLB 0.6), and polyoxyethylene sorbitan monolaurate (PSML, HLB 16.7) (purity 95.0\%) were supplied by Il-Sin Co., Ltd. (Seoul, Korea). Market milk (3.8\% milk fat) was purchased from Seoul Dairy Co-op. (Seoul, Korea). 2-thiobarbituric acid (TBA) was obtained from Sigma Chemical Co. (St. Louis, MO, USA).

\section{High extraction of peanut sprout}

Peanut sprout was extracted according to the method of Yoo et al. (2012). Water was added to it (8 times) and steamed at $95^{\circ} \mathrm{C}$ for $4 \mathrm{~h}$ (1st steaming). The 2 nd steaming followed the procedure as the 1 st steaming. After the 2 nd steaming, water was added to steam peanut sprouts (5 times) and it was extracted by water. The extract was filtered through a Whatman filter paper and was concentrated to $60 \mathrm{Brix}$ at $95^{\circ} \mathrm{C}$ for 48 to $60 \mathrm{~h}$ by vacuum evaporator. Resveratrol in the peanut sprout was quantified using high pressure liquid chromatography (Agilent Technologies, 1200 series, Santa Clara, CA, USA) with UV detection, equipped with a Waters Sunfire $\mathrm{C}_{18}$ column (150 $\mathrm{mm} \times 4.6 \mathrm{~mm}, 5 \mu \mathrm{m}$ particle size, Phenomenex, Torrance,
CA, USA). The temperature was controlled at $25^{\circ} \mathrm{C}$. Mobile phase consisted of an acetonitrile and water, with a flow rate of $0.6 \mathrm{ml} / \mathrm{min}$. Injection volume was $20 \mu \mathrm{l}$. Detection was performed at a $306 \mathrm{~nm}$ wavelength.

\section{Microencapsulation of peanut sprout extract}

Microencapsulation was prepared by adopting the method of Park et al. (2006). Primary emulsion of peanut sprout extract ( $1 \mathrm{mg} / \mathrm{ml}), 1 \%$ PGPR (HLB 0.6) and primary coating material MCT were prepared by mixing with homogenizer (WiseMix ${ }^{\mathrm{TM}}$ HG15A, Daihan Scientific, Seoul, Korea) at 9,000 rpm for $2 \mathrm{~min}$. Secondary emulsion (W/O/W) was then made by mixing the primary emulsions, secondary coating material $30 \%$ WPC and 1\% PSML (HLB 16.7 ) at 2,000 rpm for $10 \mathrm{~min}$ following the addition of a proportion of coating materials to the core material and emulsifier. The W/O/W emulsions were fed into a spray dryer (Eyela spray dryer SD-1000, Eyela, Tokyo, Japan). Flow rate of feeding pump was $800 \mathrm{ml} / \mathrm{h}$, while inlet and outlet temperatures of the drying chamber were 170 and $70^{\circ} \mathrm{C}$, respectively.

\section{Manufacture of powdered microcapsule-added milk}

Powdered peanut sprout extract microcapsules (PPSEM) were added to $10 \mathrm{ml}$ of milk at various concentrations $(0.5,1.0,1.5,2.0,2.5$ and $3.0 \%)$ and mixed with vortex mixer (Vortex genie ${ }^{\circledR} 2$, Scientific Industries, New York, NY, USA) for $5 \mathrm{~min}$. The milk supplemented with PPSEM was aseptically syringed into a $200 \mathrm{ml} \mathrm{milk}$ pack. The PPSEM-supplemented milk pack was then stored at $4^{\circ} \mathrm{C}$ for $0,4,8,12$ and $16 \mathrm{~d}$ for various analyses.

\section{Scanning electron microscopy}

A scanning electron microscope (SEM, Hitachi S-4700, Tokyo, Japan) was used to analyze the microstructure of the powdered microcapsules from peanut sprout extract coated with WPC.

pH

$\mathrm{pH}$ values of PPSEM-supplemented milk samples were measured at $4^{\circ} \mathrm{C}$ using a $\mathrm{pH}$ meter (Orion 900A, Madison, WI, USA).

\section{Release of powdered peanut sprout extract microcapsules in milk}

The release of PPSEM in milk was determined by the modified method of Singleton et al. (1999). The PPSEMsupplemented milk sample $(0.2 \mathrm{ml})$ was mixed with $200 \mu \mathrm{l}$ of freshly prepared Folin-Ciocalteu reagent using a vortex mixer. After $3 \mathrm{~min}, 2 \mathrm{ml}$ of sodium carbonate $(15 \%$, w/v) were added and the mixture was allowed to stand for 30 min at room temperature. The absorbance at $750 \mathrm{~nm}$ was measured using a spectrophotometer. Sample blank was 
prepared in the same manner except deionized water was used instead of Folin-Ciocalteu reagent. Total phenolic content was expressed as $\mathrm{mg}$ of gallic acid equivalent by using an equation from the gallic acid calibration curve. All samples were measured in triplicate.

\section{Oxidation studies in milk}

The oxidation of PPSEM in milk was evaluated by the thiobarituric acid reactive substance (TBARS) method of Stapelfeldt et al. (1997). First of all, TBA solution was made by dissolving 2-thiobarbituric acid (1.4 g) in $95 \%$ ethanol to $100 \mathrm{ml}$. PPSEM-supplemented milk (17.6 ml) was taken into a flask fitted with glass stopper, heated to $30^{\circ} \mathrm{C}$, added $1 \mathrm{ml}$ trichloroacetic acid (TCA) solution containing $1 \mathrm{~g} / \mathrm{ml}$, followed by $95 \%$ ethanol $(2 \mathrm{ml})$, stopped and shaked for $10 \mathrm{~s}$. After $5 \mathrm{~min}$, the contents were filtered through Whatman No. 42. One ml of the TBA solution was added into $4 \mathrm{ml}$ of the clear filtrate. The contents were mixed and placed in the water bath at $60^{\circ} \mathrm{C}$ for $1 \mathrm{~h}$ followed by cooling in an ice bath for $10 \mathrm{~min}$. Absorbance was read at $450 \mathrm{~nm}$ with a UV-VIS-NIR scanning spectrophotometer (Beckman coulter, inc., Fullerton, CA, USA). Each sample was measured at least three times.

\section{Color measurement}

Color values of milk sample supplemented with PPSEM were measured using a colorimeter (CR210, Minolta, Tokyo, Japan) after calibrating its original value with a standard plate $(X=97.83, Y=81.58, Z=91.51)$. Measured $L^{*}$, a* and $b^{*}$ values were used as indicators of lightness, redness and yellowness, respectively.

\section{Sensory analysis}

Eight-trained sensory panelists evaluated randomly coded milk samples supplemented with PPSEM and control (without the supplement of PPSEM). The color, rancidity, bitterness, astringency and overall acceptability were investigated on a 7 -point scale $(1=$ very weak, $4=$ moderate, $7=$ very strong).

\section{Statistical analysis}

All statistical analyses were performed using SAS version 9.0 (SAS Institute Inc., Cary, NC, USA). An ANOVA was performed using the general linear models procedure to determine significant differences among the samples. Means were compared by using Fisher's least significant difference procedure. Significance was defined at the $5 \%$ level.

\section{RESULTS AND DISCUSSION}

\section{Scanning electron microscopy}

The SEM image of the powdered microcapsules from peanut sprout extract coated material WPC are shown in Figure 1. The average size of the microcapsules was about 3 to $10 \mu \mathrm{m}$ as measured by scanning electron microscopy. The resveratrol content of peanut sprout extract by high extraction method was found to be about $153 \mu \mathrm{g} / \mathrm{ml}$.

pH

The changes in $\mathrm{pH}$ values of milk samples supplemented with various concentrations of PPSEM and control (without supplement of PPSEM) during $16 \mathrm{~d}$ of storage at $4{ }^{\circ} \mathrm{C}$ are shown in Figure 2. Initially $\mathrm{pH}$ values were proportionally decreased with increasing concentrations $(0.5,1.0,1.5,2.0,2.5$ and $3.0 \%)$ of the PPSEM and this trend continued to the final period of storage and ranged from 6.81 to 6.62 which is in the normal scope of market milk. The $\mathrm{pH}$ values for all the milk samples were nearly constant during $16 \mathrm{~d}$ storage and ranged from 6.6 to 6.8 , as a reflective of the fresh state (Lee et al., 2006). These results indicated that the various concentrations of PPSEM supplement did not cause an adverse effect on the $\mathrm{pH}$ of the milk during the storage of $16 \mathrm{~d}$.

\section{Release of powdered peanut sprout extract microcapsules in milk}

The releasing rate of resveratrol in the PPSEMsupplemented milk during storage at $4^{\circ} \mathrm{C}$ for $16 \mathrm{~d}$ is shown in Figure 3. The rate increased proportionally with the concentration and storage of the PPSEM-supplemented milk. However, the lower concentrations $(0.5$ and $1.0 \%)$ of PPSEM-supplemented milk showed the lower level of resveratrol release with $1 \%$ out of $0.89 \mu \mathrm{l}$ per ml. The greater the release of resveratrol, the more the quality of the milk as well as the properties of resveratrol will be affected. Therefore, lower concentrations (0.5 and 1.0\%) of PPSEMsupplemented milk could have greater functional value of

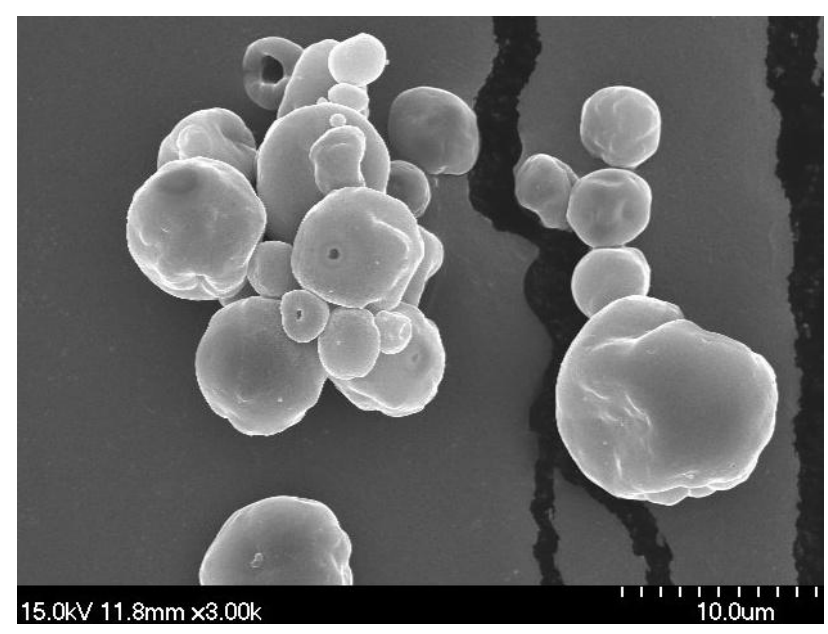

Figure 1. Scanning electron microphotographs (SEM) of powdered microcapsules of peanut sprout extract. 


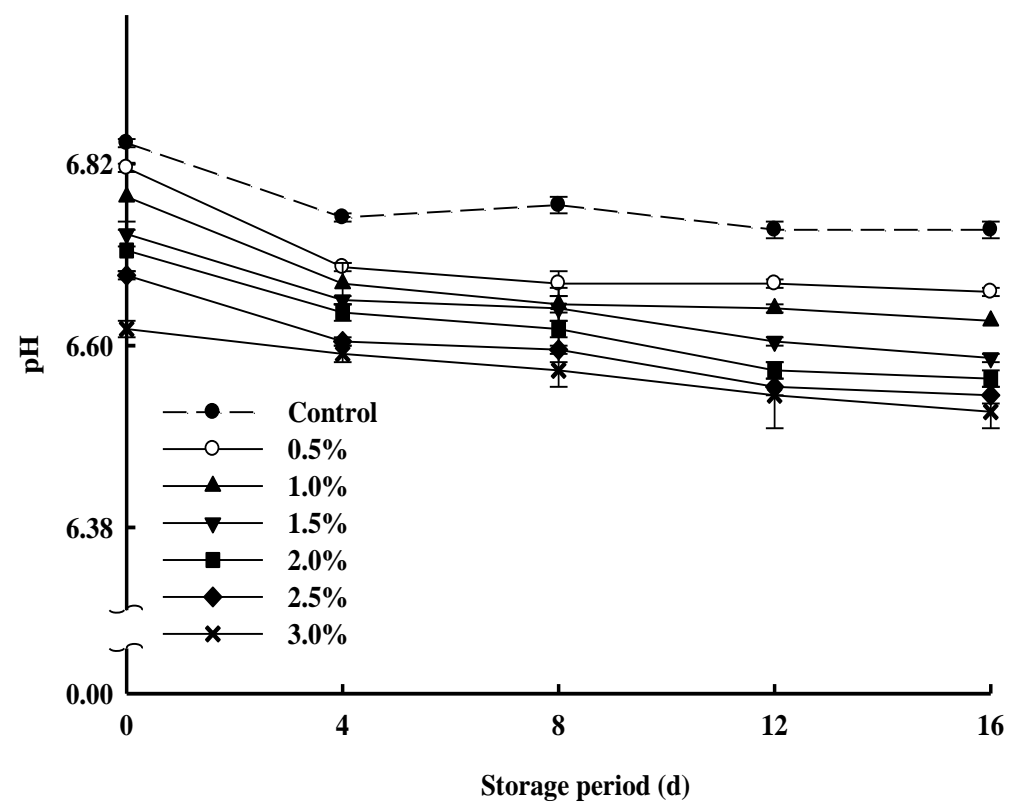

Figure 2. Changes in $\mathrm{pH}$ of powdered peanut sprout extract microcapsule-supplemented milk stored at $4^{\circ} \mathrm{C}$ for $16 \mathrm{~d}$.

milk during storage up to $16 \mathrm{~d}$.

\section{Changes of the thiobarituric acid reactive substance}

The changes in TBARS of PPSEM-supplemented milk during storage at $4^{\circ} \mathrm{C}$ for $16 \mathrm{~d}$ are shown in Figure 4. TBARS absorbance values ranging below 0.2 indicated mostly lower oxidation in the milk. TBARS increased proportionally with increasing concentrations of the PPSEM-supplemented milk during storage. However, it did not exceed 0.2 until $4 \mathrm{~d}$ storage except $3 \%$ supplementation of PPSEM in milk which exceeded 0.2 from $0 \mathrm{~d}$. However, 0.5 and $1.0 \%$ PPSEM-supplemented milks maintained the lower value of 0.2 up to $16 \mathrm{~d}$. These results are in accordance with the findings of Tuohy et al. (1981) and Ipsen and Hansen (1988) which stated that increasing storage time favored more oxidation and increased the TBARS value in whole milk powder. Also, freeze-dried milk powder and spray-dried milk powder were observed where TBA values increased with the increasing storage during 20 d (Kim et al., 2010). Further, Ahn et al. (2010) reported that TBA-values of encapsulated I. obliquus extract-added milk samples increased during storage. Therefore, the results indicated that there was no considerable chemical oxidation in the 0.5 and $1.0 \%$ PPSEM-supplemented milk samples during the $16 \mathrm{~d}$ storage.

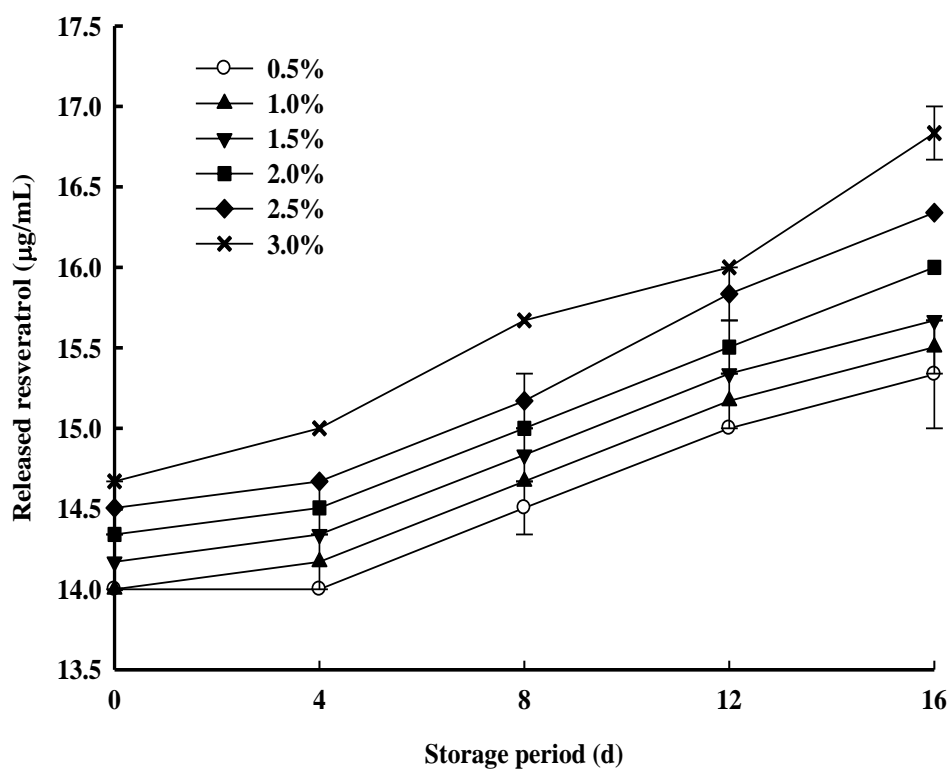

Figure 3. Measurement of resveratrol for released powdered peanut sprout microcapsule-supplemented milk stored at $4{ }^{\circ} \mathrm{C}$ for $16 \mathrm{~d}$. 


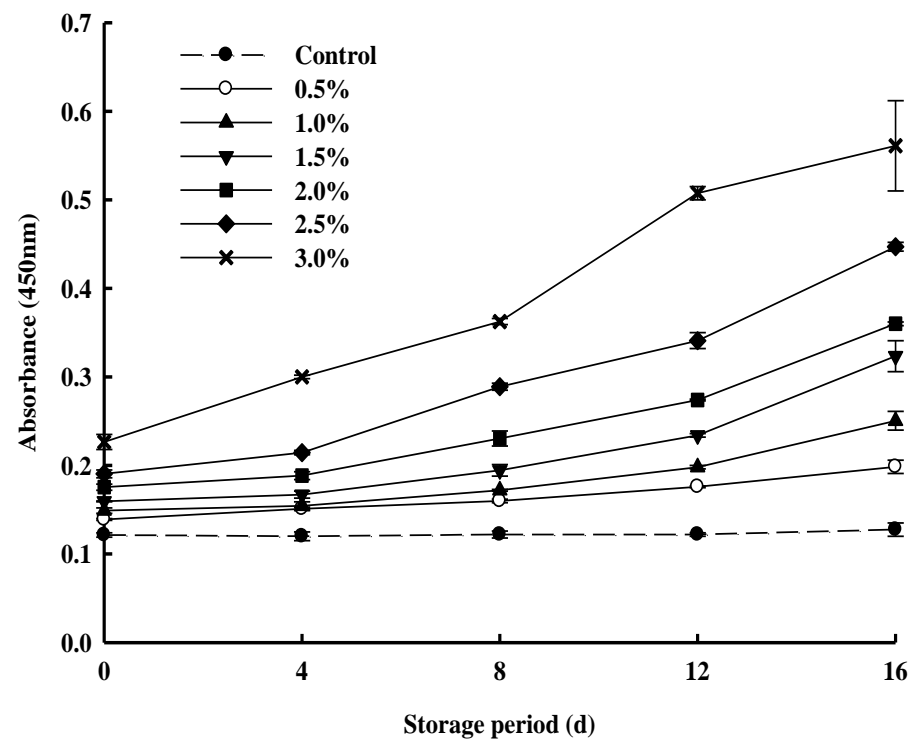

Figure 4. Changes in thiobarbituric acid reactive substance (TBARS) value of powdered peanut sprout extract microcapsulesupplemented milk stored at $4^{\circ} \mathrm{C}$ for $16 \mathrm{~d}$.

\section{Color}

The changes in color of PPSEM-supplemented milk samples stored at $4^{\circ} \mathrm{C}$ for $16 \mathrm{~d}$ are presented in Table 1 . The $\mathrm{L}^{*}$ values of the milk supplemented with higher concentrations of PPSEM (1.5, 2.0, 2.5 and 3.0\%) were significantly higher at $0 \mathrm{~d}(\mathrm{p}<0.05)$. However, increasing storage period of $16 \mathrm{~d}$ did not affect the $\mathrm{L}^{*}$ values irrespective of treatments ( $>00.05)$. According to Philips et al. (1995), the $\mathrm{L}^{*}$ value of milk has been demonstrated to have the most positive impact on consumer appeal. However, in this study, it is speculated that the supplementation of the PPSEM in milk samples would not influence the consumer appeal over the extended storage of $16 \mathrm{~d}$. Since the microcapsules are normally light yellow, it

Table 1. Changes in color of powdered peanut sprout extract microcapsule-supplemented milk stored at $4^{\circ} \mathrm{C}$ for $16 \mathrm{~d}$

\begin{tabular}{|c|c|c|c|c|c|c|}
\hline \multirow{2}{*}{ Color } & \multirow{2}{*}{ Conc. (\%) } & \multicolumn{5}{|c|}{ Storage period (d) } \\
\hline & & 0 & 4 & 8 & 12 & 16 \\
\hline \multirow{7}{*}{$\begin{array}{l}\mathrm{L}^{*} \\
\text { (lightness) }\end{array}$} & Control & $88.47 \pm 0.78^{1 \mathrm{~dB} 2}$ & $90.33 \pm 0.14^{\mathrm{bA}}$ & $89.14 \pm 0.28^{\mathrm{cB}}$ & $90.13 \pm 0.35^{\mathrm{dA}}$ & $88.91 \pm 0.27^{\mathrm{cB}}$ \\
\hline & 0.5 & $88.64 \pm 0.60^{\mathrm{dB}}$ & $90.69 \pm 0.36^{\mathrm{bA}}$ & $89.55 \pm 0.44^{\mathrm{bB}}$ & $90.25 \pm 0.21^{\mathrm{dA}}$ & $89.29 \pm 0.15^{\mathrm{bB}}$ \\
\hline & 1.0 & $89.18 \pm 0.17^{\mathrm{cAB}}$ & $90.94 \pm 0.26^{\mathrm{abA}}$ & $90.30 \pm 0.16^{\mathrm{aB}}$ & $90.60 \pm 0.11^{\mathrm{bB}}$ & $89.34 \pm 0.10^{\mathrm{bB}}$ \\
\hline & 1.5 & $89.69 \pm 0.13^{\mathrm{aB}}$ & $91.39 \pm 0.29^{\mathrm{abAB}}$ & $90.43 \pm 0.14^{\mathrm{aB}}$ & $90.93 \pm 0.22^{\mathrm{aB}}$ & $89.60 \pm 0.21^{\mathrm{aB}}$ \\
\hline & 2.0 & $89.97 \pm 0.13^{\mathrm{bB}}$ & $92.32 \pm 0.29^{\mathrm{aA}}$ & $90.18 \pm 0.10^{\mathrm{aB}}$ & $90.74 \pm 0.10^{\mathrm{aAB}}$ & $89.31 \pm 0.14^{\mathrm{bB}}$ \\
\hline & 2.5 & $89.83 \pm 0.18^{\mathrm{bB}}$ & $91.66 \pm 0.21^{\mathrm{bA}}$ & $90.09 \pm 0.25^{\mathrm{aB}}$ & $90.81 \pm 0.24^{\mathrm{abA}}$ & $89.46 \pm 0.17^{\mathrm{abB}}$ \\
\hline & 3.0 & $90.17 \pm 0.10^{\mathrm{bB}}$ & $91.02 \pm 0.20^{\mathrm{abAB}}$ & $90.15 \pm 0.21^{\mathrm{aB}}$ & $90.51 \pm 0.23^{\mathrm{cbB}}$ & $89.52 \pm 0.13^{\mathrm{abB}}$ \\
\hline \multirow{7}{*}{$\begin{array}{l}\mathrm{a}^{*} \\
\text { (redness) }\end{array}$} & Control & $2.17 \pm 0.28^{\mathrm{bC}}$ & $2.50 \pm 0.06^{\mathrm{cB}}$ & $2.55 \pm 0.12^{\mathrm{bB}}$ & $2.76 \pm 0.20^{\mathrm{aA}}$ & $2.78 \pm 0.14^{\mathrm{aA}}$ \\
\hline & 0.5 & $2.18 \pm 0.19^{\mathrm{bC}}$ & $2.60 \pm 0.16^{\mathrm{aB}}$ & $2.73 \pm 0.21^{\mathrm{aB}}$ & $2.78 \pm 0.10^{\mathrm{aAB}}$ & $2.81 \pm 0.10^{\mathrm{aA}}$ \\
\hline & 1.0 & $2.33 \pm 0.10^{\mathrm{bC}}$ & $2.67 \pm 0.10^{\mathrm{aB}}$ & $2.74 \pm 0.07^{\mathrm{aA}}$ & $2.78 \pm 0.04^{\mathrm{aA}}$ & $2.80 \pm 0.10^{\mathrm{aA}}$ \\
\hline & 1.5 & $2.68 \pm 0.05^{\mathrm{aA}}$ & $2.68 \pm 0.11^{\mathrm{aA}}$ & $2.80 \pm 0.04^{\mathrm{aA}}$ & $2.83 \pm 0.42^{\mathrm{aA}}$ & $2.83 \pm 0.10^{\mathrm{aA}}$ \\
\hline & 2.0 & $2.70 \pm 0.05^{\mathrm{aB}}$ & $2.76 \pm 0.06^{\mathrm{abB}}$ & $2.86 \pm 0.02^{\mathrm{aA}}$ & $2.85 \pm 0.06^{\mathrm{aA}}$ & $2.89 \pm 0.03^{\mathrm{abA}}$ \\
\hline & 2.5 & $2.71 \pm 0.10^{\mathrm{aB}}$ & $2.86 \pm 0.08^{\mathrm{bc} A \mathrm{~B}}$ & $2.88 \pm 0.03^{\mathrm{aA}}$ & $2.89 \pm 0.10^{\mathrm{aA}}$ & $2.92 \pm 0.02^{\mathrm{bA}}$ \\
\hline & 3.0 & $2.76 \pm 0.02^{\mathrm{aB}}$ & $2.76 \pm 0.03^{\mathrm{abB}}$ & $2.88 \pm 0.05^{\mathrm{aA}}$ & $2.87 \pm 0.02^{\mathrm{aA}}$ & $2.90 \pm 0.06^{\mathrm{bA}}$ \\
\hline \multirow{7}{*}{$\begin{array}{l}\mathrm{b}^{*} \\
\quad \text { (yellowness) }\end{array}$} & Control & $1.70 \pm 0.78^{\mathrm{dC}}$ & $2.67 \pm 0.15^{\mathrm{eB}}$ & $3.03 \pm 0.35^{\mathrm{eAB}}$ & $3.10 \pm 0.23^{\mathrm{dAB}}$ & $3.29 \pm 0.34^{\mathrm{dA}}$ \\
\hline & 0.5 & $2.10 \pm 0.57^{\mathrm{dC}}$ & $3.31 \pm 0.46^{\mathrm{dB}}$ & $3.58 \pm 0.59^{\mathrm{dAB}}$ & $3.93 \pm 0.28^{\mathrm{cA}}$ & $3.97 \pm 0.21^{\mathrm{cA}}$ \\
\hline & 1.0 & $2.83 \pm 0.20^{\mathrm{cC}}$ & $3.97 \pm 0.36^{\mathrm{cB}}$ & $4.78 \pm 0.24^{\mathrm{cA}}$ & $4.82 \pm 0.16^{\mathrm{bA}}$ & $4.85 \pm 0.14^{\mathrm{bA}}$ \\
\hline & 1.5 & $4.63 \pm 0.19^{\mathrm{bAB}}$ & $4.73 \pm 0.43^{\mathrm{bAB}}$ & $4.97 \pm 0.22^{\mathrm{bcB}}$ & $4.92 \pm 0.36^{\mathrm{bAB}}$ & $4.94 \pm 0.30^{\mathrm{bB}}$ \\
\hline & 2.0 & $4.64 \pm 0.18^{\mathrm{bC}}$ & $5.05 \pm 0.45^{\mathrm{bAB}}$ & $5.31 \pm 0.11^{\mathrm{abA}}$ & $5.00 \pm 0.10^{\mathrm{bAB}}$ & $5.35 \pm 0.18^{\mathrm{bA}}$ \\
\hline & 2.5 & $5.02 \pm 0.31^{\mathrm{bC}}$ & $5.16 \pm 0.31^{\mathrm{bC}}$ & $5.54 \pm 0.40^{\mathrm{aAB}}$ & $5.62 \pm 0.28^{\mathrm{aAB}}$ & $5.76 \pm 0.18^{\mathrm{abA}}$ \\
\hline & 3.0 & $5.76 \pm 0.02^{\mathrm{aAB}}$ & $5.61 \pm 0.34^{\mathrm{aB}}$ & $5.58 \pm 0.34^{\mathrm{aB}}$ & $5.64 \pm 0.30^{\mathrm{aB}}$ & $5.97 \pm 0.29^{\mathrm{aA}}$ \\
\hline
\end{tabular}

${ }^{1}$ Mean $\pm S D(n=8) .{ }^{2}$ Values with different superscript in a row (A-D) and column (a-c) are significant at $p<0.05$ by Duncan's multiple range test. 
was that the value of $a^{*}$ and $b^{*}$ values for the PPSEM- of milk. supplemented milk sample increased with increasing storage time. Higher concentrations of the supplementation of PPSEM $(1.5,2.0,2.5$ and $3.0 \%)$ in milk was found to increase the $b^{*}$ values during storage of $16 \mathrm{~d}$. However, the lower concentrations $(0.5$ and $1.0 \%)$ of PPSEMsupplemented milk showed similar $b^{*}$ values to the control $(\mathrm{p} \leq 0.05)$. On the basis of results obtained from this study, it is suggested that the lower concentrations $(0.5$ and $1.0 \%)$ of PPSEM supplementation does not markedly affect the color

\section{Sensory evaluation}

The sensory properties of PPSEM-supplemented milk stored at $4{ }^{\circ} \mathrm{C}$ for $16 \mathrm{~d}$ are shown in Table 2. Appearance, flavor and taste properties were analyzed during the increased storage time. The higher concentration (1.5, 2.0, 2.5 and $3.0 \%$ ) of the PPSEM supplementation in milk significantly increased the appearance and taste properties of milk during $16 \mathrm{~d}$ of storage $(\mathrm{p}<0.05)$. The yellowness

Table 2. Sensory characteristics ${ }^{1}$ of milk supplemented with powdered peanut sprout extract microcapsules stored at $4{ }^{\circ} \mathrm{C}$ for $16 \mathrm{~d}$

\begin{tabular}{|c|c|c|c|c|c|c|c|c|}
\hline \multirow{2}{*}{$\begin{array}{l}\text { Concentration of } \\
\text { sample }(\%, \mathrm{wt} / \mathrm{vol})\end{array}$} & \multirow{2}{*}{$\begin{array}{c}\text { Appearance } \\
\text { Color }\end{array}$} & \multicolumn{3}{|c|}{ Flavour } & \multicolumn{3}{|c|}{ Taste } & \multirow{2}{*}{$\begin{array}{c}\text { Overall } \\
\text { acceptability }\end{array}$} \\
\hline & & Rancidity & Cooked & Peanut & Astrigency & Bitterness & Sweetness & \\
\hline \multicolumn{9}{|l|}{0 -d storage period } \\
\hline Control & $1.00^{\mathrm{c} 2}$ & $1.25^{\mathrm{a}}$ & $1.50^{\mathrm{b}}$ & $1.00^{\mathrm{d}}$ & $1.38^{\mathrm{b}}$ & $1.25^{\mathrm{a}}$ & $2.00^{\mathrm{a}}$ & $5.38^{\mathrm{a}}$ \\
\hline 0.5 & $1.38^{\mathrm{c}}$ & $1.50^{\mathrm{a}}$ & $1.88^{\mathrm{ab}}$ & $1.25^{\mathrm{cd}}$ & $1.75^{\mathrm{ab}}$ & $1.50^{\mathrm{a}}$ & $2.50^{\mathrm{a}}$ & $5.00^{\mathrm{a}}$ \\
\hline 1.0 & $1.38^{\mathrm{c}}$ & $1.75^{\mathrm{a}}$ & $2.88^{\mathrm{ab}}$ & $1.25^{\mathrm{cd}}$ & $2.00^{\mathrm{ab}}$ & $1.50^{\mathrm{a}}$ & $2.75^{\mathrm{a}}$ & $4.50^{\mathrm{ab}}$ \\
\hline 1.5 & $1.63^{\mathrm{bc}}$ & $1.75^{\mathrm{a}}$ & $2.25^{\mathrm{ab}}$ & $1.38^{\mathrm{cd}}$ & $2.13^{\mathrm{a}}$ & $1.50^{\mathrm{a}}$ & $2.38^{\mathrm{a}}$ & $4.50^{\mathrm{ab}}$ \\
\hline 2.0 & $2.25^{\mathrm{ab}}$ & $1.63^{\mathrm{a}}$ & $3.00^{\mathrm{a}}$ & $2.13^{\mathrm{ab}}$ & $2.25^{\mathrm{a}}$ & $1.88^{\mathrm{a}}$ & $2.50^{\mathrm{a}}$ & $3.25^{\mathrm{b}}$ \\
\hline 2.5 & $2.50^{\mathrm{b}}$ & $1.75^{\mathrm{a}}$ & $3.25^{\mathrm{ab}}$ & $2.25^{\mathrm{ab}}$ & $2.50^{\mathrm{a}}$ & $1.50^{\mathrm{a}}$ & $2.63^{\mathrm{a}}$ & $3.13^{\mathrm{b}}$ \\
\hline 3.0 & $2.63^{\mathrm{a}}$ & $2.00^{\mathrm{a}}$ & $3.50^{\mathrm{ab}}$ & $2.38^{\mathrm{a}}$ & $2.63^{\mathrm{a}}$ & $1.50^{\mathrm{a}}$ & $2.38^{\mathrm{a}}$ & $3.25^{\mathrm{b}}$ \\
\hline \multicolumn{9}{|l|}{ 4-d storage period } \\
\hline Control & $1.25^{\mathrm{c}}$ & $1.25^{\mathrm{a}}$ & $1.75^{\mathrm{c}}$ & $1.00^{\mathrm{c}}$ & $1.38^{\mathrm{c}}$ & $1.25^{\mathrm{a}}$ & $2.25^{\mathrm{a}}$ & $5.50^{\mathrm{a}}$ \\
\hline 0.5 & $1.50^{\mathrm{bc}}$ & $1.38^{\mathrm{a}}$ & $2.13^{\mathrm{c}}$ & $1.38^{\mathrm{c}}$ & $1.88^{\mathrm{bc}}$ & $1.25^{\mathrm{a}}$ & $2.38^{\mathrm{a}}$ & $4.63^{\mathrm{ab}}$ \\
\hline 1.0 & $1.25^{\mathrm{c}}$ & $1.38^{\mathrm{a}}$ & $2.50^{\mathrm{abc}}$ & $1.38^{\mathrm{c}}$ & $1.88^{\mathrm{bc}}$ & $1.38^{\mathrm{a}}$ & $2.38^{\mathrm{a}}$ & $4.13^{\mathrm{abc}}$ \\
\hline 1.5 & $1.75^{\mathrm{bc}}$ & $1.63^{\mathrm{a}}$ & $2.63^{\mathrm{abc}}$ & $1.50^{\mathrm{bc}}$ & $2.00^{\mathrm{bc}}$ & $1.38^{\mathrm{a}}$ & $2.38^{\mathrm{a}}$ & $4.38^{\mathrm{bc}}$ \\
\hline 2.0 & $2.25^{\mathrm{ab}}$ & $1.50^{\mathrm{a}}$ & $3.13^{\mathrm{ab}}$ & $2.38^{\mathrm{ab}}$ & $2.00^{\mathrm{bc}}$ & $1.50^{\mathrm{a}}$ & $2.75^{\mathrm{a}}$ & $3.00^{\mathrm{bc}}$ \\
\hline 2.5 & $2.75^{\mathrm{a}}$ & $1.63^{\mathrm{a}}$ & $3.38^{\mathrm{a}}$ & $2.38^{\mathrm{ab}}$ & $2.25^{\mathrm{ab}}$ & $1.50^{\mathrm{a}}$ & $2.63^{\mathrm{a}}$ & $3.88^{\mathrm{bc}}$ \\
\hline 3.0 & $2.81^{\mathrm{a}}$ & $1.75^{\mathrm{a}}$ & $3.38^{\mathrm{a}}$ & $2.50^{\mathrm{a}}$ & $2.75^{\mathrm{a}}$ & $1.50^{\mathrm{a}}$ & $2.50^{\mathrm{a}}$ & $3.38^{\mathrm{bc}}$ \\
\hline \multicolumn{9}{|l|}{ 8-d storage period } \\
\hline Control & $1.00^{\mathrm{d}}$ & $1.50^{\mathrm{b}}$ & $1.38^{\mathrm{c}}$ & $1.00^{\mathrm{e}}$ & $1.25^{\mathrm{d}}$ & $1.38^{\mathrm{a}}$ & $2.13^{\mathrm{a}}$ & $5.50^{\mathrm{a}}$ \\
\hline 0.5 & $1.50^{\mathrm{cd}}$ & $1.75^{\mathrm{b}}$ & $1.88^{\mathrm{bc}}$ & $1.38^{\mathrm{de}}$ & $1.75^{\mathrm{cd}}$ & $1.38^{\mathrm{a}}$ & $2.38^{\mathrm{a}}$ & $5.00^{\mathrm{ab}}$ \\
\hline 1.0 & $1.38^{\mathrm{cd}}$ & $1.75^{\mathrm{b}}$ & $2.25^{\mathrm{ab}}$ & $1.88^{\mathrm{cde}}$ & $2.13^{\mathrm{bc}}$ & $1.50^{\mathrm{a}}$ & $2.50^{\mathrm{a}}$ & $4.38^{\mathrm{b}}$ \\
\hline 1.5 & $1.88^{\mathrm{bc}}$ & $2.13^{\mathrm{ab}}$ & $2.50^{\mathrm{ab}}$ & $2.25^{\mathrm{bc}}$ & $2.25^{\mathrm{abc}}$ & $1.50^{\mathrm{a}}$ & $2.25^{\mathrm{a}}$ & $4.50^{\mathrm{b}}$ \\
\hline 2.0 & $2.38^{\mathrm{a}}$ & $2.25^{\mathrm{ab}}$ & $2.50^{\mathrm{ab}}$ & $2.75^{\mathrm{b}}$ & $2.50^{\mathrm{abc}}$ & $2.00^{\mathrm{a}}$ & $2.25^{\mathrm{a}}$ & $3.25^{\mathrm{c}}$ \\
\hline 2.5 & $2.63^{\mathrm{a}}$ & $2.00^{\mathrm{ab}}$ & $2.75^{\mathrm{ab}}$ & $3.13^{\mathrm{b}}$ & $2.88^{\mathrm{ab}}$ & $1.75^{\mathrm{a}}$ & $2.50^{\mathrm{a}}$ & $3.00^{\mathrm{c}}$ \\
\hline 3.0 & $2.75^{\mathrm{a}}$ & $3.00^{\mathrm{a}}$ & $2.88^{\mathrm{a}}$ & $4.13^{\mathrm{a}}$ & $3.00^{\mathrm{a}}$ & $2.00^{\mathrm{a}}$ & $2.50^{\mathrm{a}}$ & $2.50^{\mathrm{c}}$ \\
\hline \multicolumn{9}{|l|}{ 12-d storage period } \\
\hline Control & $1.00^{\mathrm{d}}$ & $1.75^{\mathrm{c}}$ & $1.88^{\mathrm{c}}$ & $1.13^{\mathrm{b}}$ & $1.50^{\mathrm{b}}$ & $1.50^{\mathrm{ab}}$ & $2.63^{\mathrm{a}}$ & $5.13^{\mathrm{a}}$ \\
\hline 0.5 & $1.63^{\mathrm{cd}}$ & $2.38^{\mathrm{c}}$ & $2.13^{\mathrm{bc}}$ & $2.25^{\mathrm{a}}$ & $1.75^{\mathrm{ab}}$ & $1.50^{\mathrm{ab}}$ & $2.88^{\mathrm{a}}$ & $4.75^{\mathrm{ab}}$ \\
\hline 1.0 & $1.75^{\mathrm{c}}$ & $2.13^{\mathrm{bc}}$ & $2.52^{\mathrm{abc}}$ & $2.25^{\mathrm{a}}$ & $2.13^{\mathrm{ab}}$ & $1.38^{\mathrm{a}}$ & $2.75^{\mathrm{a}}$ & $3.75^{\mathrm{bc}}$ \\
\hline 1.5 & $2.13^{\mathrm{bc}}$ & $2.50^{\mathrm{bc}}$ & $2.63^{\mathrm{abc}}$ & $2.38^{\mathrm{a}}$ & $2.25^{\mathrm{ab}}$ & $1.50^{\mathrm{ab}}$ & $2.75^{\mathrm{a}}$ & $3.75^{\mathrm{bc}}$ \\
\hline 2.0 & $2.63^{\mathrm{b}}$ & $3.86^{\mathrm{a}}$ & $2.88^{\mathrm{a}}$ & $3.13^{\mathrm{a}}$ & $2.50^{\mathrm{a}}$ & $2.38^{\mathrm{a}}$ & $2.00^{\mathrm{a}}$ & $2.25^{\mathrm{c}}$ \\
\hline 2.5 & $3.00^{\mathrm{a}}$ & $3.86^{\mathrm{a}}$ & $3.13^{\mathrm{a}}$ & $3.00^{\mathrm{a}}$ & $3.00^{\mathrm{a}}$ & $2.00^{\mathrm{ab}}$ & $2.13^{\mathrm{a}}$ & $2.50^{\mathrm{c}}$ \\
\hline 3.0 & $3.25^{\mathrm{a}}$ & $3.38^{\mathrm{a}}$ & $3.13^{\mathrm{a}}$ & $3.00^{\mathrm{a}}$ & $3.00^{\mathrm{a}}$ & $1.88^{\mathrm{ab}}$ & $2.13^{\mathrm{a}}$ & $2.50^{\mathrm{c}}$ \\
\hline \multicolumn{9}{|l|}{ 16-d storage period } \\
\hline Control & $1.00^{\mathrm{d}}$ & $1.75^{\mathrm{c}}$ & $2.38^{\mathrm{a}}$ & $1.25^{\mathrm{d}}$ & $1.38^{\mathrm{c}}$ & $1.25^{\mathrm{c}}$ & $2.00^{\mathrm{a}}$ & $4.88^{\mathrm{a}}$ \\
\hline 0.5 & $2.13^{\mathrm{c}}$ & $2.38^{\mathrm{bc}}$ & $2.88^{\mathrm{a}}$ & $2.25^{\mathrm{c}}$ & $2.13^{\mathrm{bc}}$ & $1.38^{\mathrm{bc}}$ & $2.38^{\mathrm{a}}$ & $4.25^{\mathrm{ab}}$ \\
\hline 1.0 & $2.63^{\mathrm{c}}$ & $2.38^{\mathrm{bc}}$ & $3.00^{\mathrm{a}}$ & $2.75^{\mathrm{bc}}$ & $2.63^{\mathrm{b}}$ & $2.00^{\mathrm{abc}}$ & $2.25^{\mathrm{a}}$ & $3.50^{\mathrm{bc}}$ \\
\hline 1.5 & $2.38^{\mathrm{c}}$ & $2.88^{\mathrm{bc}}$ & $3.00^{\mathrm{a}}$ & $3.13^{\mathrm{abc}}$ & $2.63^{\mathrm{b}}$ & $1.63^{\mathrm{abc}}$ & $2.25^{\mathrm{a}}$ & $3.25^{\mathrm{bc}}$ \\
\hline 2.0 & $3.25^{\mathrm{ab}}$ & $3.75^{\mathrm{abc}}$ & $3.00^{\mathrm{a}}$ & $3.63^{\mathrm{ab}}$ & $3.63^{\mathrm{a}}$ & $2.38^{\mathrm{ab}}$ & $2.38^{\mathrm{a}}$ & $2.25^{\mathrm{c}}$ \\
\hline 2.5 & $3.50^{\mathrm{a}}$ & $4.13^{\mathrm{abc}}$ & $3.13^{\mathrm{a}}$ & $3.63^{\mathrm{ab}}$ & $3.63^{\mathrm{a}}$ & $2.50^{\mathrm{a}}$ & $2.00^{\mathrm{a}}$ & $2.38^{\mathrm{c}}$ \\
\hline 3.0 & $3.63^{\mathrm{a}}$ & $4.13^{\mathrm{a}}$ & $3.13^{\mathrm{a}}$ & $3.88^{\mathrm{a}}$ & $3.88^{\mathrm{a}}$ & $2.25^{\mathrm{a}}$ & $2.00^{\mathrm{a}}$ & $2.38^{\mathrm{c}}$ \\
\hline
\end{tabular}

\footnotetext{
${ }^{1}$ The scale of appearance, flavor, taste and color scores: $1=$ very week, $4=$ moderate, $7=$ very strong. ${ }^{2}$ Mean \pm SD $(n=8)$
}

${ }^{\mathrm{a}-\mathrm{d}}$ Values with different superscripts within the same column differ significantly $(\mathrm{p}<0.05)$. 
scores were also greatly increased with higher level of PPSEM in milk. It was well correlated with a higher $b^{*}$ value of milk (Table 1). Rancidity off-flavor was found to be similar to a lower concentration $(0.5 \%)$ of PPSEM supplementation during $8 \mathrm{~d}$ storage. Peanut and cooked offflavor scores were significantly increased with higher concentrations $(1.5,2.0,2.5$ and $3.0 \%)$ of PPSEM supplementation and storage of $16 \mathrm{~d}(\mathrm{p}<0.05)$. It was well correlated with a higher release of resveratrol during increasing storage time (Figure 3). Jeon et al. (2005) reported that the addition of MCT as a coating material for the microencapsulated isoflavone in milk slightly but not significantly increased the color, off-flavor, bitterness, astringency and off-taste values. In overall acceptability, the lower concentration $(0.5$ and $1.0 \%)$ of PPSEMsupplemented milk showed a similar value to milk up to $8 \mathrm{~d}$. Thus the low concentrations $(0.5$ and $1.0 \%)$ of PPSEM can be used as a supplement in milk without affecting the sensory properties.

In the conclusion of this study, the data on $\mathrm{pH}$, color and sensory analysis indicated that the lower concentrations $(0.5$ to $1.0 \%$ ) of PPSEM could be applicable in the development of functional milk. Furthermore, it confirms that low concentrations (0.5 and $1.0 \%)$ PPSEM-supplemented milk minimizes the release rate of resveratrol, and it does not affect the supplemented milk quality. The production of the milk which incorporates the PPSEM can broaden the utilization of peanut sprout extract, and the products can be regarded as possible health-promoting nutraceutical foods.

\section{ACKNOWLEDGEMENTS}

This study was supported by a grant from Small and Medium Business Administration in Seoul, Republic of Korea.

\section{REFERENCES}

Adachi, S., H. Imaoka, H. Ashida, H. Maeda, and R. Matsuno. 2004. Preparation of microcapsules of W/O/W emulsions containing a polysaccharide in the outer aqueous phase by spray-drying. Eur. J. Lipid Sci. Technol. 106:225-231.

Ahn, S. L., Y. H. Chang, and H. S. Kwak. 2010. Optimization of microencapsulation of Inonotus obliquus extract powder by response surface methodology and its application into milk. Korean J. Food Sci. Anim. 30:661-668.

Burns, J., T. Yokota, H. Ashihara, M. E. J. Lean, and A. Crozier. 2002. Plant foods and herbal sources of resveratrol. J. Agric. Food Chem. 50:3337-3340.

Cho Y. H., D. S. Shin, and J. Park. 2000. Optimization of emulsification and spray drying process for the microencapsulation of flavor compounds. Korean J. Food Sci. Technol. 32:132-139.

Fomolla, J., E. Lopez-Huertas, F. J. Machado, D. Molina, I. Alvarez, E. Marmol, M. Navas, E. Palacin, M. J. Garcia-Valls,
B. Remon, J. J. Boza, and J. L. Marti. 2009. Milk enriched with "health fatty acids" improves cardiovascular risk markers and nutritional status in human volunteers. J. Nutr. 25:408-414.

Gharsallaoui, A., G. Roudaut, O. Chambin, A. Vioilley, and R. Saurel. 2007. Applications of spray-drying in microencapsulation of food ingredients: An overview. Food Res. Int. 40:1107-1121.

Gurbuz, O., D. Gocmen, F. Dagdelen, M. Gursoy, S. Aydin, I. Sahin, L. Buyukuysal, and M. Usta. 2007. Determination of Flavan-3-ols and trans-resveratrol in grapes and wine using HPLC with fluorescence detection. Food Chem. 100:518-525.

Ipsen, R., and P. S. Hansen. 1988. Factors affecting the storage stability of whole milk powder. (Report No. 274). Statens of Mejeriforsog, Hillerod, Denmark.

Jeon, B. J., N. C. Kim, E. M. Han, and H. S. Kwak. 2005. Application of microencapsulated isoflavone into milk. Arch. Pharm. Res. 28:859-865.

Kang, H. I., J. Y. Kim, K. W. Park, J. S. Kang, M. R. Choi, K. D. Moon, and K. I. Seo. 2010. Antioxidative effect of peanut sprout extracts. J. Korean Soc. Food Sci. Nutr. 39:941-946.

Kim, S. H., Y. H. Chang, and H. S. Kwak. 2010. Physicochemical properties of reconstituted milk made from freeze-dried milk powder or spray-dried milk powder. Korean J. Food Sci. Anim. 30:28-35.

King, R. E., J. A. Bomser, and D. B. Min. 2006. Bioactivity of resveratrol. Compr. Rev. Food Sci. Food Saf. 5:65-70.

Lee, J. B., J. Ahn, J. Lee, and H. S. Kwak. 2004. L-ascorbic acid microencapsulated with polyacylglycerol monostearate for milk fortification. Biosci. Biotech. Biochem. 68:495-500.

Lee, S. J., J. H. Hwang, S. H. Kim, S. G. Min, and H. S. Kwak. 2006. Comparison of the physicochemical properties of freezeconcentrated versus evaporated milk. Food Sci. Biotechnol. 15:844-850.

Lyons, M. M., C. Yu, R. B. Toma, S. Y. Cho, W. Reiboldt, J. Lee, and R. B. Van Breemen. 2003. Resveratrol in raw and baked blueberries and bilberries. J. Agric. Food Chem. 51:5867-5870.

Mizutani, K., K. Ikeda, Y. Kwawai, and Y. Yamori. 1998. Resveratrol stimulates the proliferation and differentiation of osteoblastic MC3T3-E1 cells. Biochem. Biophys. Res. Commun. 253:859-863.

Park. B. G., J. H. Lee, H. K. Shin, J. H. Lee, and P. S. Chang. 2006. Optimization of conditions for the double layer microencapsulation of lactic acid bacteria. Korean J. Food Sci. Technol. 38:767-772.

Pedroza-Islas, R., E. J. Vernon-Carter, C. Duran-Dominguez, and S. Trejo-Martinez. 1999. Using biopolymer blends for shrimp feedstuff microencapsulation-I. Microcapsule particle size, morphology and microstructure. Food Res. Int. 32:367-374.

Philips, L. G., M. L. McGrief, D. M. Barbano, and H. A. Lawless. 1995. The influence of fat on the sensory properties, viscosity polymers: chemistry, solubility and fiber formation. Prog. Polym. Sci. 34:641-678.

Singleton, V. L., R. Orthofer, and R. M. Lamuela-Raventos. 1999. Analysis of total phenols and other oxidation substrates and antioxidants by means of Folin-Ciocalteu reagent. Method Enzymol. 299:152-178.

Stapelfeldt, H., B. R. Nielsen, and L. H. Skibsted. 1997. Effect of heat treatment, water activity and storage temperature on the oxidative stability of whole milk powder. Int. Dairy J. 7:331- 
339.

Subbaramaiah, K., W. J. Chung, P. Michaluart, N. Telang, T. Tanabe, H. Inoue, M. Jang, J. M. Pezzuto, and A. J. Dannenberg. 1998. Resveratrol inhibits cyclooxygenase-2 transcription and activity in phorbol ester-treated human mammary epithelial cells. J. Biol. Chem. 273:21875-21882.

Surh, Y. J., K. S. Chun, H. H. Cha, S. S. Han, Y. S. Keum, K. K. Park, and S. S. Lee. 2001. Molecular mechanisms underlying chemopreventive activities of anti-inflammatory phytochemicals: down-regulation of COX-2 and iNOS through suppression of NF-kappa B activation. Mutat. Res. 480-481:243-268.

Tokusoglu, O., M. K. Unal, and F. Yemis. 2005. Determination of phytoalexin in peanut and pistachios by HPLC-DAD and GCMS. J. Agric. Food Chem. 53:5003-5009.
Tuohy, J. J., D. O’Leary, and P. M. Kelly. 1981. Packaging and storage of whole milk powder. Int. J. Food Sci. Technol. 5:82.

Wang, Y., F. Catana, Y. Yang, R. Roderick, and R. B. van Breemen. 2002. An LC-MS method for analyzing total resveratrol in grape juice, cranberry juice, and in wine. J. Agric. Food Chem. 50:431-435.

Yoo, A. Y., and H. S. Kwak. 2012. Methodology development of high extracted peanut sprout. Kor. Appl. Patent No 10-20120094906.

Zeng, L., Z. Ding, M. Zhang, and Jincai. Sun. 2011. Microencapsulation of bayberry polyphenols by ethyl cellulose: preparation and characterization. J. Food Eng. 104:89-95. 